\title{
Efektifitas Penggunaan Games Edukasi untuk Meningkatkan Kemampuan dan Hasil Belajar Siswa dengan Aplikasi Mobile Learning pada Mata Kuliah Computer Programming
}

\author{
Patmah Fatoni ${ }^{1}$, Mira Rosalina ${ }^{2}$ \\ ${ }^{1,2}$ Program Studi Teknik Informatika \\ ${ }^{1}$ Universitas Lintas Internasional Indonesia, Tangerang Selatan \\ ${ }^{2}$ Sekolah Tinggi Keguruan dan Ilmu Pendidikan Surya Tangerang \\ Email : patmah.fatoni@iuli.ac.id ${ }^{1}$, mira.rosalina@stkipsurya.ac.id ${ }^{2}$
}

\begin{abstract}
ABSTRAK
Mata kuliah Computer Programming merupakan mata kuliah yang cukup banyak menyita waktu dalam menjelaskan model, kode sumber, rangkaian instruksi dan fungsi spesifik pada bahasa komputer, dan setiap mahasiswa membutuhkan konsentrasi agar dapat memahami dan mengerti mata kuliah computer programming dalam waktu satu semester. Namun mahasiswa mengalami kejenuhan sehingga isi mata kuliah tidak dapat tersampaikan dengan baik oleh karena itu penelitian ini menggunakan metode proses pembelajaran menggunakan games edukasi dalam satu semester. Bahasa pemrograman fungsional dan bahasa pemrograman logikal yang terdapat dalam mata kuliah computer programming dapat disampaikan melalui games edukasi yang memiliki operasi matematika dan sumber kode yang dibutuhkan dalam modus interaktif yang dapat diterjemahkan dan dieksekusi lebih mendalam dan sederhana.

Games edukasi ini merupakan media pembelajaran yang bersifat mendidik, mandiri dan merdeka dalam menjalankan pembelajaran, diharapkan mahasiswa dapat berpikir kreatif, inovatif dan produktif secara asyik dan menyenangkan. Metode penelitian pengambilan data menggunakan model pembelajaran mobile learning berupa tutorial, latihan praktek, penemuan dan simulasi pengambilan data. Dengan games edukasi aplikasi mobile learning, mahasiswa dapat meningkatkan kemampuan dan hasil belajar pada mata kuliah computer programming dengan melakukan metode penelitian secara kuantitatif berupa angka dan analisa menggunakan teknik statistika yang dapat dilihat dari hasil normalisasi gain yang diperoleh sebesar 0.52 atau $52 \%$ termasuk ke dalam kategori sedang atau sebagian besar mahasiswa mengalami peningkatan hasil belajar. Penggunaan games edukasi mobile learning cukup efektif digunakan untuk meningkatkan hasil belajar mahasiswa dilihat dari nilai normalisasi gain dan respon belajar mahasiswa dalam pencapaian pembelajaran yang terarah dan tercapai seluruh isi satuan pembelajaran mata kuliah computer programming.

Dengan meningkatnya hasil belajar yang diperoleh maka mahasiswa memiliki kepercayaan diri yang lebih, dapat merancang tujuan lebih detail dan dapat menerima serta mempelajari hal baru yang meningkatkan ilmu dan keterampillannya.
\end{abstract}

Kata kunci : games edukasi, media pembelajaran, computer programming, efektifitas hasil belajar, normalisasi gain, mobile learning 


\begin{abstract}
The Computer Programming is a course that takes a lot of time in explaining models, source code, a series of instructions and specific functions in computer language, and every student needs concentration or focus more detail in order to understand computer programming courses within one semester. However, students experience boredom so that the content of the course cannot be conveyed properly, therefore this study uses a learning process method using educational games in one semester. The functional programming language and logical programming language contained in the computer programming course can be delivered through educational games that have the required mathematical operations and source code in an interactive mode that can be translated and executed in a more profound and simple way.

An educational game is a game designed to teach students about a specific subject and to teach them a skill learning. it is expected that students can think creatively, innovatively, productively and fun. With mobile application learning students can improve learning objective of the subject computer programing. For this research we have done quantitative research methods, in the form of numbers and analysis using statical techniques.The result of normalization gain is 0.52 or $52 \%$ (middle category) in the point is majority of students have increased learning outcomes. Students learned educational games effective with they use their mobile smartphone for learning computer programming. We can see the result from normalization gain and response students.

With the increase in learning outcomes obtained, students have more confidence, can design more detailed goals and can accept and learn new things that improve their knowledge and skills.
\end{abstract}

Keywords : educational game, instructional media, computer programing, learning objective, normalization gain, mobile learning

\title{
1. PENDAHULUAN
}

Pada dunia pendidikan informatika komputer memiliki tujuan untuk mengaplikasikan dan mengintegrasikan ilmu komputer dengan ilmu kependidikan yang bersifat multimedia secara interaktif maupun e-learning. Pendidikan informatika dan komputer mempelajari ilmu pedagogik dan computer programming, dua disiplin ilmu yang berbeda namun memiliki sistem komunikasi pendidikan yang penting.

Pemanfaatkan smartphone merupakan model pembelajaran mobile learning yang memanfaatkan teknologi informasi dan komunikasi melalui konsep pembelajaran dengan melakukan instrumen penelitian melakukan pretest, tindakan games edukasi berbasiskan mobile learning untuk mengetahui efektivitas kemampuan dan hasil belajar siswa dengan menggunakan games edukasi (Sung \& Hwang, 2013). 
Berdasarkan latar belakang pada penelitian ini, peneliti melihat adanya efektifitas waktu dan fungsi secara otomatis dalam meningkatkan kemampuan dan hasil belajar siswa jika penerapan games edukasi mobile learning dibuat dan diterapkan dalam dunia pendidikan khususnya pendidikan teknik informatika dan komputer mata kuliah computer programming.

Penelitian ini memiliki rumusan masalah dan tujuan penelitian yaitu : (1) Membangun sistem perkuliahan computer programming yang bersifat mobile dan cepat diakses dimanapun berada, (2) Menentukan nilai parameter secara optimal sebagai pengguna games edukasi dan mengetahui keefektifan media permainan sebagai media pembelajaran (Arsyad, 2015) dalam proses kegiatan belajar mengajar, (3) Mengetahui repon siswa yang menggunakan media games edukasi dengan aplikasi mobile learning.

Computer programming adalah suatu proses yang digunakan untuk menulis kode dengan menginstruksikan bagaimana komputer, aplikasi, atau program perangkat lunak bekerja atau seperangkat instruksi untuk memfasilitasi tindakan yang dijalankan komputer dengan menulis dan menguji kode sehingga memungkinkan aplikasi dan program perangkat lunak dapat beroperasi dengan sukses (Knuth, 1997).

Scratch adalah software pemrograman pendidikan terbaik yang tersedia saat ini, belum ada alat lain yang membuat pemrograman dengan mudah dari dasar. Ada beberapa banyak produk serupa telah terinspirasi oleh software ini (Sweigart, 2016).

Blockly adalah bahasa pemrograman antarmuka grafis yang membuatnya dapat menyenangkan untuk pemula dalam mempelajari seni inovasi melalui penjelasan rinci dan aktivitas langsung yang dibangun untuk menumbuhkan kreativitas dan pemecahan masalah untuk pemograman. (Rearick, 2017)

Beberapa literature yang terdapat pada bagian ini adalah dasar teori dalam membangun pondasi awal dari penelitian ini. Konsep dasar tentang efektifitas penggunaan games edukasi untuk meningkatkan kemampuan dan hasil belajar siswa dengan aplikasi mobile learning pada mata kuliah computer programming.

Media pembelajaran adalah sebuah perantara atau alat bantu yang digunakan untuk membuat peserta didik supaya belajar guna untuk mencapai tujuan pembelajaran (Djamarah \& Zain, 2013). Media pembelajaran terdiri atas dua unsur penting, yaitu: (1) Unsur peralatan atau perangkat keras (hardware), yaitu sarana atau prasarana yang digunakan untuk menyampaikan pesan, (2) Unsur pesan yang dibawanya 
message/software), yaitu informasi atau materi atau bahan ajar dalam tema atau topik pembelajaran tertentu dalam hal ini computer programming materi pemograman web yang akan disampaikan atau dipelajari oleh siswa.

Terdapat empat model pembelajaran dengan menggunakan mobile learning: (1) Model Tutorial (Tutorials), (2) Model Latihan dan Praktek (Drill and Practice), (3) Model Penemuan (Problem Solving), (4)Model Simulasi (Simulations). Model Pembelajaran yang dilakukan pada penelitian ini yaitu berdasarkan pada gambar 1 :

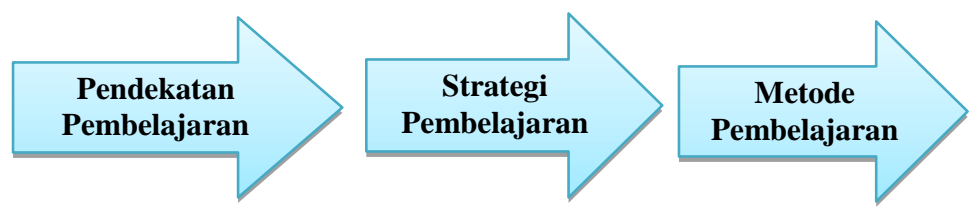

Gambar 1: Model Pembelajaran

Hasil belajar adalah tingkat keberhasilan siswa dalam mempelajari computer programming yang dinyatakan dalam skor, dimana skor tersebut didapat oleh siswa dari hasil tes mengenai sejumlahmateri. Hasil belajar meliputi pemahaman tentang : (1) Konsep (Aspek Kognitif), (2) Keterampilan Proses (Aspek Psikomotor), (3) Sikap Siswa (Aspek Afektif) (Suharsimi Arikunto, Supardi, 2015).

\section{METODE PENELITIAN}

Penelitian ini dilakukan dengan menggunakan proses pendekatan terstruktur dan metode model analisis desain yang memiliki tujuan untuk memahami basic programming dengan menggunakan games edukasi dalam kegiatan pembelajaran. Metode yang digunakan dalam penelitian ini adalah metode pra eksperimen dengan desain kelompok tunggal pretes dan posttest (one group pretest-postest design) dimana pada metode ini penelitian hanya dilakukan pada satu kelompok dan kelompok tersebut akan diberikan perlakuan dengan pembelajaran. Desain penelitian ini observasi dilakukan sebanyak dua kali, yaitu sebelum dan sesudah eksperimen,observasi yang dilakukan sebelum eksperimen disebut pretes, dan observasi yang dilakukan setelah eksperimen disebut posttest (Sugiyono, 2012). Perbedaan selisih nilai antara pretes dan posttest diasumsikan sebagai efek dari adanya treatment atau adanya penerapan penggunaan game edukasi. Secara umum, desain penelitiannya dapat digambarkan sebagai berikut : 


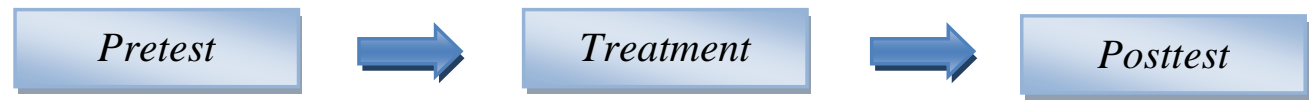

Gambar 2: Desain one group pretest-posttest design

Mahasiswa diberikan pretest terlebih dahulu, kemudian dilanjutkan dengan memberikan perlakuan menggunakan media games edukasi (X) kemudian diberikan posttest untuk dapat melihat hasil belajar mahasiswa. Kemudian data pretest dan posttest diolah, dianalisis untuk dapat mengukur seberapa efektifitas media games edukasi dalam meningkatkan hasil belajar mahasiswa.

Pengambilan data dilakukan di Sekolah Tinggi Keguruan Ilmu pendidikan Surya. Pada semester gasal dan genap tahun ajaran 2016 kelas computer programming dengan jumlah mahasiswa yang mengambil mata kuliah tersebut sebanyak 25 mahasiswa.

Kemudian langkah prosedur penelitian selanjutnya dilakukan pada pengembangan media pembelajaran (game edukasi) terdiri dari langkah berikut ini : (1) Analisa kebutuhan jenis materi basic computer programming yang akan dikembangkan dalam media pembelajaran game edukasi, (2) Desain media pembelajaran yang merupakan proses perancangan dan pengembangan basic computer programming disesuaikan dengan karateristik mahasiswa pada kelas penelitian, (3) Implementasi media pembelajaran yaitu proses pengembangan aplikasi pembelajaran berupa mobile learning pada games edukasi untuk pembelajaran computer programming, (4) Pengujian games edukasi pada tahap ini peneliti melakukan tahap uji coba aplikasi mobile learning kemudian melakukan evaluasi media pembelajaran, (5) Pemeliharaan dalam penelitian games edukasi yang telah diujicobakan pada penelitian ini yaitu meningkatkan kualitas soal setiap tingkat kesulitannya.

Tolak ukur hasil pendidikan dapat kita ketahui dengan adanya evaluasi. Evaluasi pendidikan bentuk pengukuran atau penilaian hasil belajar-mengajar, padahal antara keduanya punya arti berbeda meskipun saling berhubungan. Mengukur adalah membandingkan sesuatu dengan satu ukuran (kuantitatif), sedangkan menilai berarti mengambil suatu keputusan terhadap sesuatu dengan ukuran baik buruk (kualitatif), adapun pengertian evaluasi meliputi keduanya. (Arikunto, 2013)

Instrumen pengumpulan data yang digunakan dalam penelitian ini yaitu teknik pengambilan data berbentuk pilihan ganda untuk mengukur kemampuan siswa sebelum diberi perlakuan dan setelah diberi perlakuan dan teknik pengambilan data kuesioner 
(angket) yang dilakukan dengan memberikan beberapa pertanyaan untuk melihat hasil dan evaluasi media pembelajaran games edukasi untuk mengetahui respon siswa terhadap media tersebut. Teknik pengolahan data berupa metode penelitian kuantitatif berupa angka dan analisa menggunakan teknik statistika (Sugiyono, 2012).

Pada penelitian ini adalah data dari hasil pretest dan posttest langkah yang dilakukan adalah sebagai berikut:

\section{(1) Pemberian skor nilai}

$\mathrm{N}$ : Nilai siswa

$$
N=\left\{\frac{\sum B}{\sum S}\right\} \cdot N M
$$

$\sum \mathrm{B}$ : Jumlah skor siswa yang menjawab soal benar

$\sum \mathrm{S}$ : Jumlah skor maksimal soal

NM : Nilai maksimal (100)

\section{(2) Pengelolaan data pretest dan posttest}

Pengolahan data pretest dan posttest, dianalisis dengan melakukan langkah analisa sampel dan menghitung nilai rata-rata menggunakan rumus:

$$
\bar{X}=\frac{\sum_{i=1}^{n} f i x i}{\sum_{i=1}^{n} f i}
$$

$\bar{X}=$ Nilai rata-rata

fi $=$ Frekuensi untuk nilai xi pada data

$\mathrm{xi}=$ Nilai ujian

(3) Menghitung nilai normalisasi gain (N-gain)

$$
N \text { gain }=\frac{\text { Skor }_{\text {postest }}-\text { Skor }_{\text {pretest }}}{\text { Skor } \text { maksimum }_{\text {matest }}-\text { Skor }_{\text {pretest }}}
$$

Sumber : (Meltzer, 2002)

Kreteria peningkatan gain sebagai berikut :

Tabel 1. Kriteria Peningkatan

\begin{tabular}{cc}
\hline Gain ternormalisasi & Kriteria Peningkatan \\
\hline $\mathrm{G}<0.5$ & Rendah \\
\hline $0.5 \leq \mathrm{G} \leq 0.5$ & Sedang \\
\hline $\mathrm{G}>0.7$ & Tinggi
\end{tabular}


Sumber : (Meltzer, 2002)

Menilai kemampuan hasil belajar berdasarkan kriteria berikut ini:

Tabel 2. Kriteria Kemampuan Hasil Belajar

\begin{tabular}{cc}
\hline Nilai (\%) & Kriteria Kemampuan \\
\hline $81-100$ & Sangat Baik \\
\hline $61-80$ & Baik \\
\hline $41-60$ & Cukup \\
\hline $21-40$ & Kurang \\
\hline $0-20$ & Sangat Kurang
\end{tabular}

Sumber: (Arikunto, 2013)

Menilai peningkatan hasil belajar mahasiswa

Tabel 3. Peningkatan Hasil Belajar

\begin{tabular}{cc}
\hline Tafsiran Persentase & Tafsiran Kualitatif \\
\hline 0 & Tidak ada \\
\hline $1-25$ & Sebagian kecil \\
\hline $26-49$ & Hampir separuhnya \\
\hline 50 & Separuhnya \\
\hline $51-75$ & Sebagian besar \\
\hline $76-99$ & Hampir seluruhnya \\
\hline 100 & Seluruhnya \\
\hline
\end{tabular}

Sumber : (Arikunto, 2013)

\section{(4) Melakukan Analisa Statistika}

Uji statistika dilakukan dengan menguji signifikansi perbedaan rata-rata antara skor pretes dan posttest mahasiswa secara keseluruhan dengan menggunakan program SPSS versi 12.0 (SPSS Versi 12, 2008) melalui tahapan berikut: (Sugiyono, 2012)

(1) Uji normalitas dengan menggunakan tes Kolmogorov-Smirnov (Daniel, n.d.) dengan penafsiran sebagai berikut: jika probabilitas (nilai signifikansi) > 0,05 maka sampel terdistribusi normal dan jika probabilitas (nilai signifikansi) $<0,05$, maka sampel tidak terdistribusi normal. 
(2) Uji signifikansi menggunakan tes Wilcoxon (taraf kesalahan $5 \%$ ) apabila terdapat satu atau dua data dari dua kelompok yang diperoleh terdistribusi tidak normal, dengan penafsiran sebagai berikut : jika probabilitas yaitu asymptot signifikansi > 0,05, maka $\mathrm{H}_{\mathrm{o}}$ diterima, sehingga dapat disimpulkan tidak ada perbedaan yang signifikan antara skor pretest dan posttest berupa peningkatan hasil belajar, sedangkan jika probabilitas yaitu asymptot signifikansi $<0,05$, maka $\mathrm{H}_{\mathrm{o}}$ ditolak, sehingga dapat disimpulkan ada perbedaan yang signifikan antara skor pretest dan posttest berupa peningkatan hasil belajar.

(3) Uji signifikansi menggunakan tes Paired Sample T Test apabila terdistribusi normal dengan penafsiran sebagai berikut : jika probabilitas yaitu asymptot signifikansi > 0,05, maka $\mathrm{H}_{\mathrm{o}}$ diterima, sehingga disimpulkan tidak ada perbedaan yang signifikan antara skor pretes dan skor posttest berupa peningkatan hasil belajar, sedangkan jika probabilitas yaitu asymptot signifikansi $<0,05$, maka $\mathrm{H}_{\mathrm{o}}$ ditolak, sehingga disimpulkan ada perbedaan yang signifikan antara skor pretes dan posttest berupa peningkatan hasil belajar.

\section{(5) Angket Penelitian}

Kuesioner atau angket penelitian diisi atau dijawab untuk melihat kepuasan atau keefektifan dari media game edukasi yang telah digunakan oleh peneliti dan mahasiswa dalam kegiatan pembelajaran pada materi basic computer programming. Angket ini diolah dengan menggunakan skala likert (Joshi et al., 2015).

\section{HASIL DAN PEMBAHASAN}

Penelitian ini dilakukan dengan menggunakan proses pendekatan terstruktur dan metode model analisis desain (Gall, M. D, Gall, J. P., Borg, 2007) yang memiliki tujuan untuk memahami seberapa efektif penggunaan games edukasi sebagai media pembelajaran yang dapat meningkatkan kemampuan dan hasil belajar siswa dengan menggunakan aplikasi yang berada dalam smartphone mahasiswa khususnya untuk dapat memahami basic computer programming. Tampilan permainan blockly dan scratch yang digunakan mahasiswa sebagai berikut ini: 


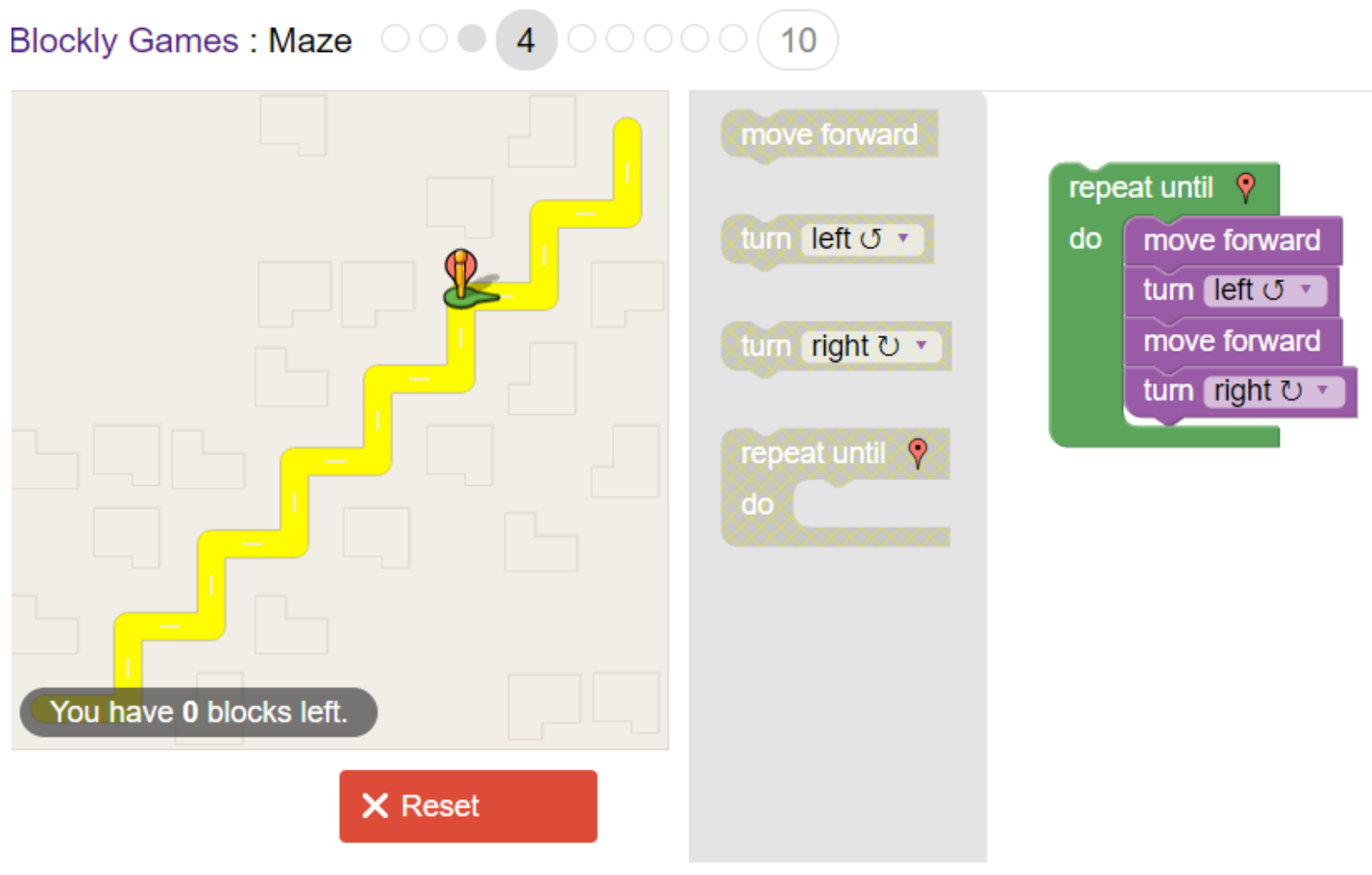

Gambar 3. Tampilan Permainan Blockly Sumber: (Blockly, 2016)

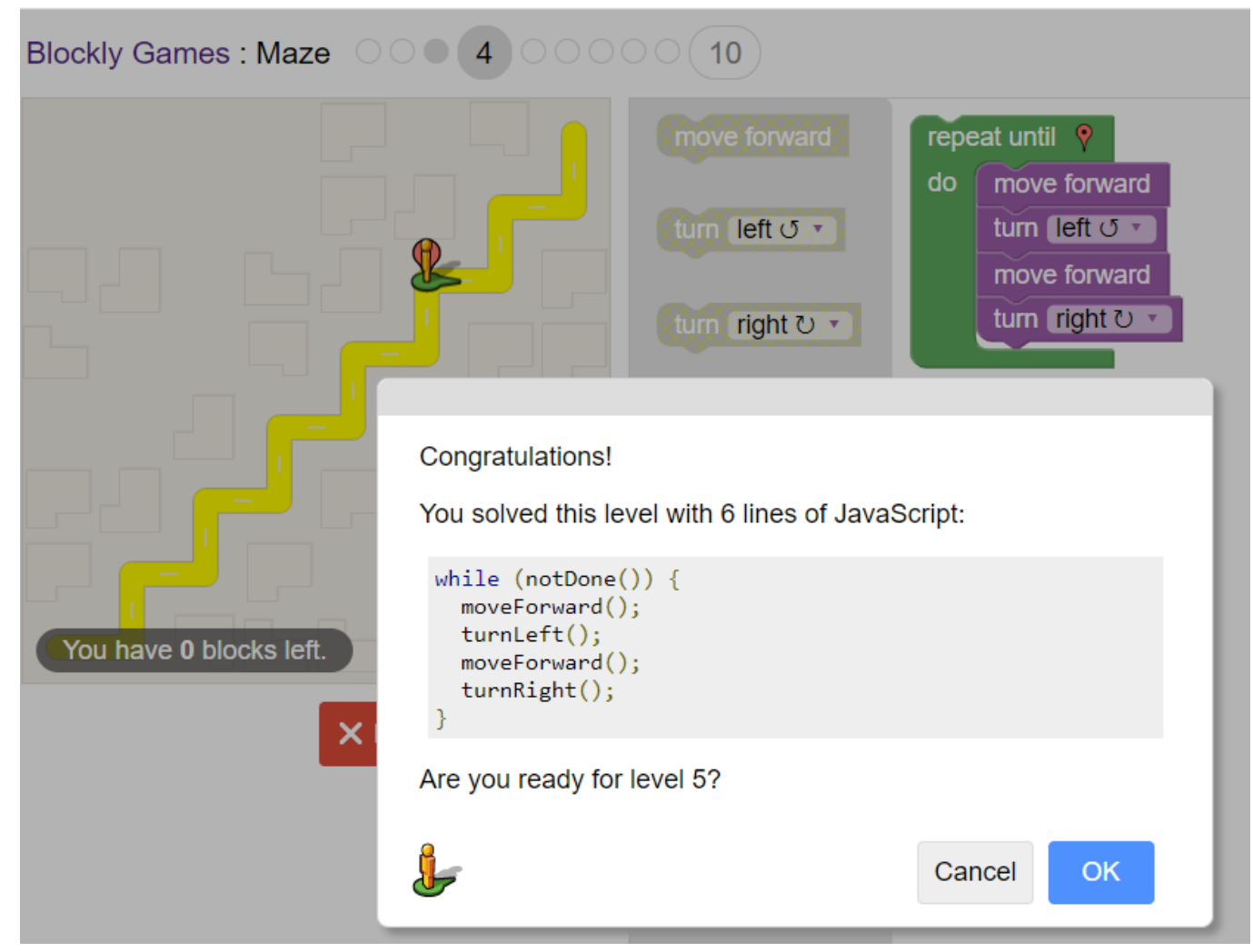

Gambar 4. Tampilan Permainan coding Blockly

Sumber : (Blockly, 2016) 


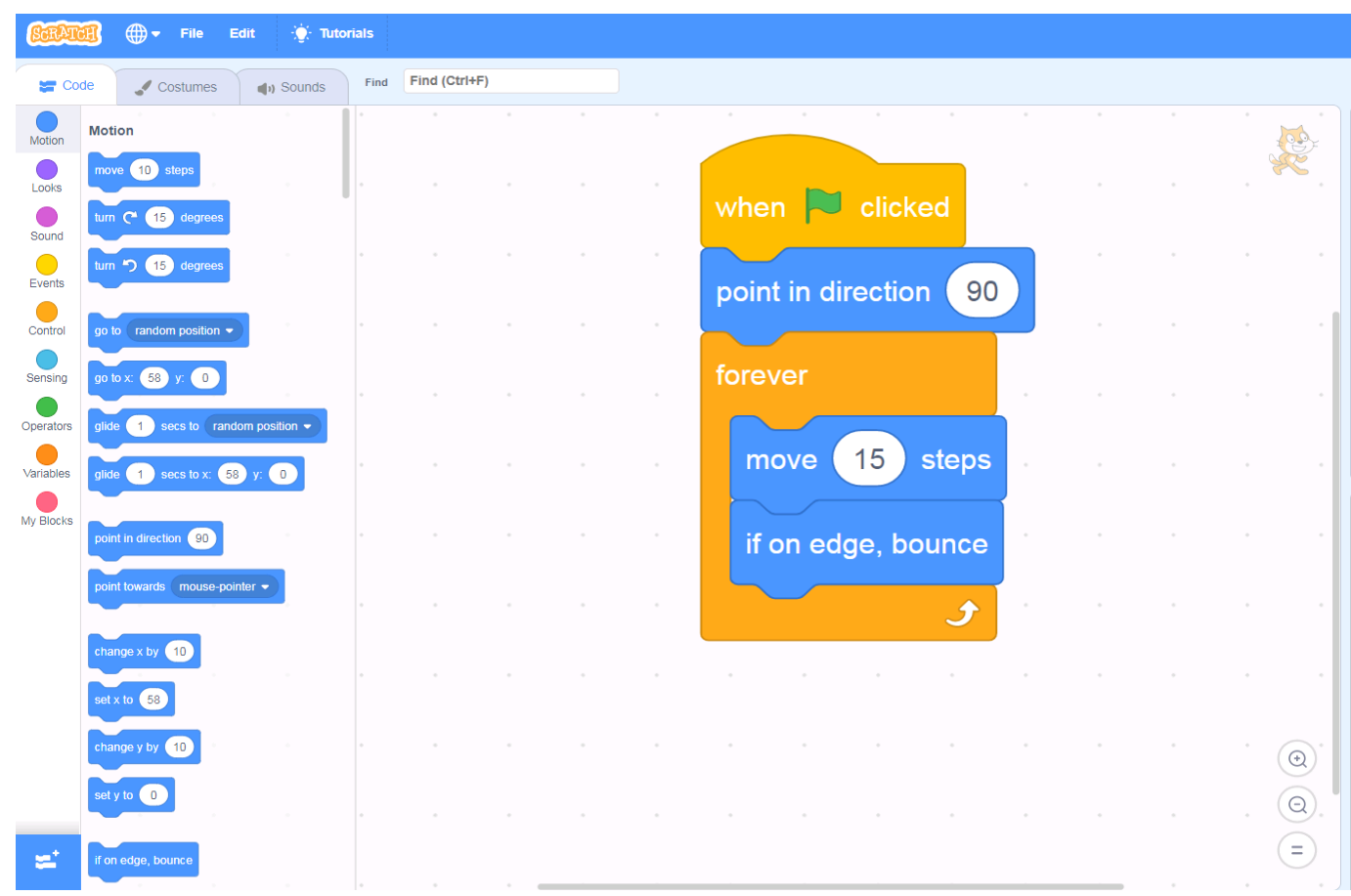

\section{Gambar 5. Tampilan Permainan Scratch}

Sumber : (Scratch, 2016)

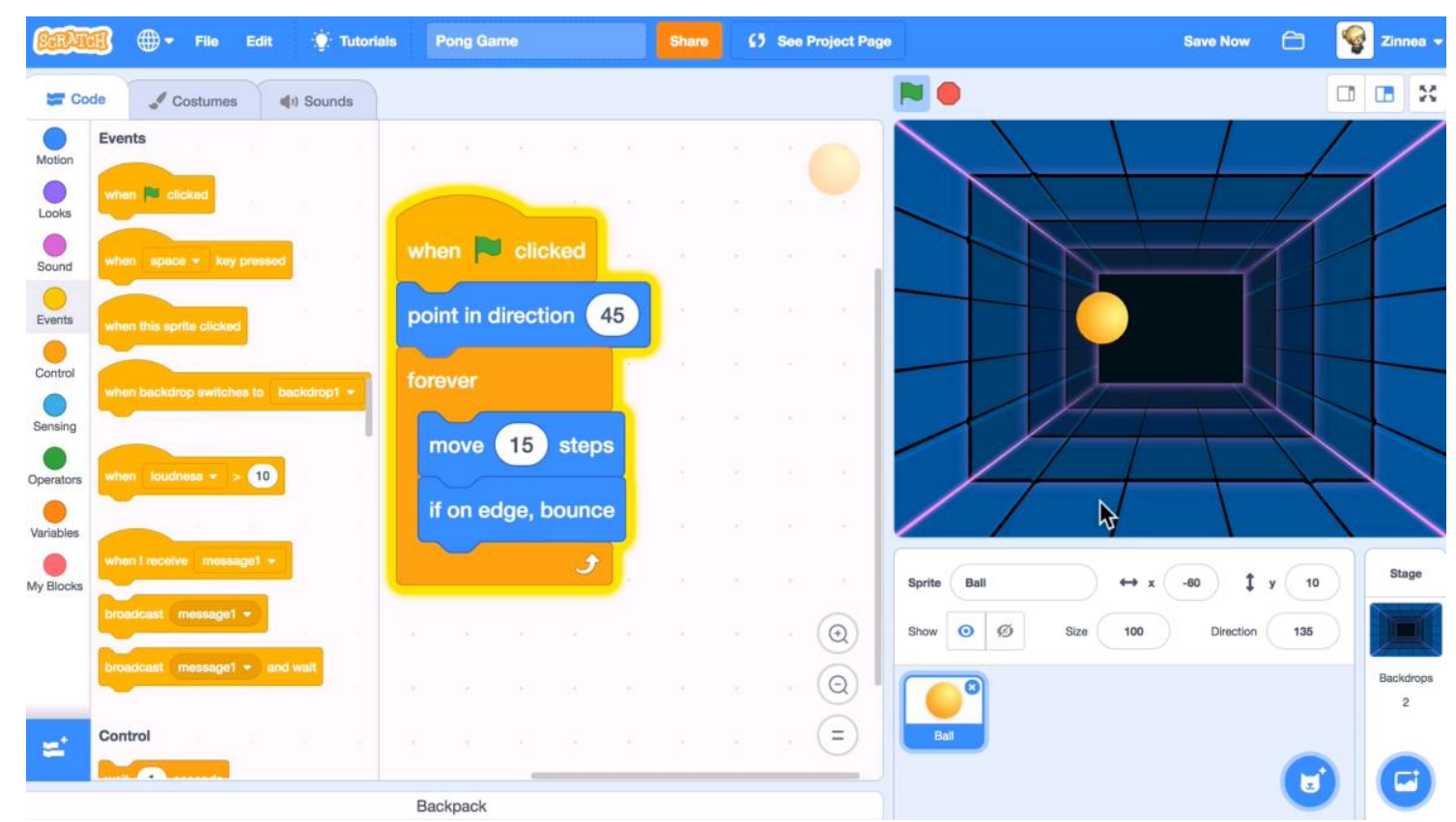

Gambar 6. Tampilan Permainan coding Scratch Sumber : (Scratch, 2016)

Hasil analisa data penelitian diperoleh dari data secara keseluruhan yang diukur berdasarkan hasil pretest dan posttest sehingga menghasilkan nilai berikut ini: 
Tabel 4. Nilai Rata-rata Kelas Pretest-Posttest Penelitian Basic Computer Programming Tafsiran Peningkatan Hasil Belajar

\begin{tabular}{cccc}
\hline No & & Pre Test & Post Test \\
\hline 1 & Nilai rata-rata & 69.8 & 85.1 \\
\hline 2 & Standar Deviasi & 16.11999 & 8.4 \\
\hline 3 & Varians & 259.8542 & 70.56 \\
\hline 4 & Nilai Maksimal & 95 & 100 \\
\hline 5 & Nilai Minimal & 45 & 75
\end{tabular}

Sumber: Data Sekunder, diolah (2017)

Dari pengolahan data diperoleh rata-rata gain yang ternormalisasi sebesar 0,52 dengan kategori sedang Selain itu diperoleh pula kriteria kemampuan mahasiswa yaitu kemampuan awal yang ditunjukkan dengan rata-rata nilai pretest sebesar 69,8 dan kemampuan mahasiswa setelah penggunaan game edukasi yang ditunjukkan dengan nilai rata-rata posttest sebesar 85,1 .

Dengan demikian, berdasarkan tafsiran kemampuan menurut Arikunto (2002) yang terdapat pada tabel 2 menunjukkan bahwa kemampuan awal mahasiswa tergolong baik dan kemampuan akhir mahasiswa setelah penggunaan game edukasi tergolong sangat baik. Adapun normalisasi gain tertinggi yang diperoleh siswa adalah sebesar 1 yaitu pada mahasiswa nomor 5, 24, dan 25. Sedangkan normalisasi gain terendah sebesar 0.17 yaitu pada siswa nomor 6 .

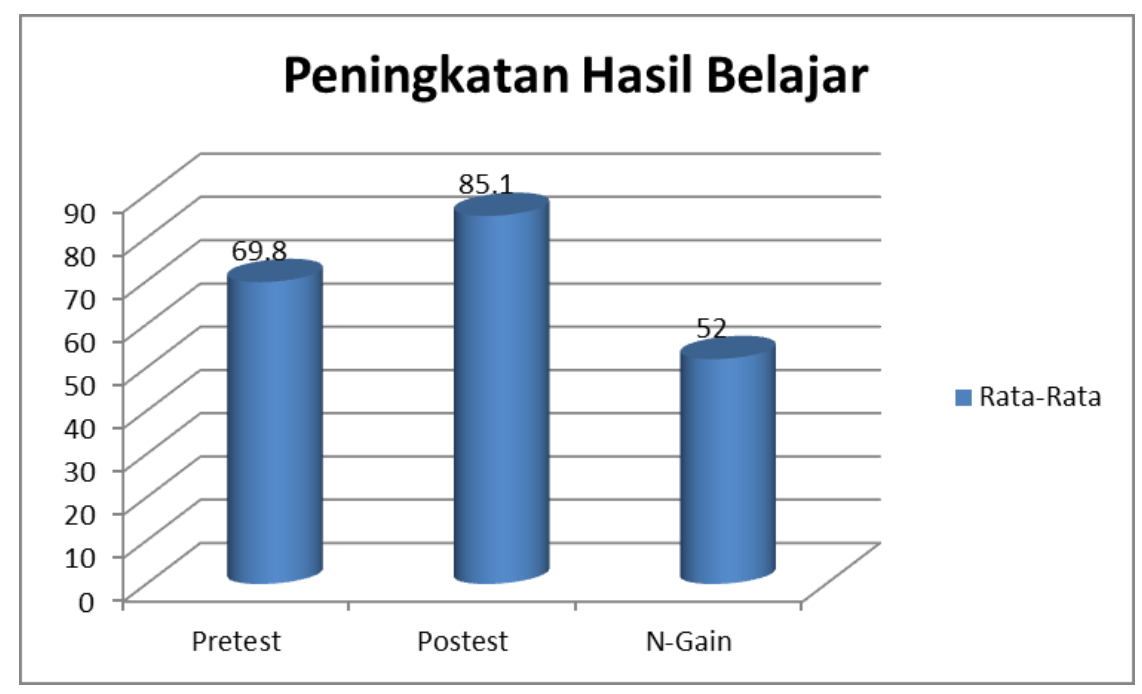

Gambar 7: Grafik Nilai Pretest, Posttest, dan Gain Ternormalisasi Siswa secara Keseluruhan 
Pada gambar 7 memberikan gambaran mengenai rata-rata kemampuan hasil belajar mahasiswa pada pretest dan posttest yang mengalami peningkatan berupa normalisasi gain.

Berdasarkan grafik di atas didapatkam bahwa secara umum mahasiswa mengalami peningkatan dengan rata-rata normalisasi gain sebesar 52\%. Dengan kata lain, menurut tafsiran (Koentjaraningrat, 1990) yang terdapat dalam tabel 3 dapat disimpulkan bahwa sebagian besar maha siswa mengalami peningkatan hasil belajar setelah diterapkan game edukasi.

\section{(1) Uji Normalitas}

Hasil pengolahan nilai data ini perlu dikuatkan oleh pengolahan statistik untuk menguji lebih jelas dan terarah apakah peningkatan hasil belajar terjadi secara signifikan atau tidak.Adapun langkah yang dilakukan adalah sebagai berikut:

Tabel 5. One Sample Kolmogorov-Smirnov Test

\begin{tabular}{llr}
\hline & & Nilai Pretest \\
\hline $\mathrm{N}$ & & 25 \\
\hline Normal Parameter & & Mean \\
\cline { 2 - 3 } & Std. Deviation & 69.800 \\
\hline Most Extreme Differences & Absolute & 16.1200 \\
\cline { 2 - 3 } & Positive & 0.153 \\
\cline { 2 - 3 } & Negative & 0.153 \\
\hline Test Statistic & & 0.120 \\
\hline Asymp. Sig. (2-tailed) & & $0.132^{\mathrm{c}}$ \\
\hline a. Test distribution is Normal. & \\
b. Calculated from data. & \\
c. Lilliefors Significance Correction. & \\
\hline
\end{tabular}

Sumber: Data Sekunder, diolah (2017)

Berdasarkan uji normalitas diperoleh nilai signifikasi pretest sebesar 0.132. Karena nilai signifikansi > 0.05 maka data pretest terdistribusi normal. Diperoleh data statistic uni normalitas posttest sebagai berikut: 
Tabel 6. One-Sample Kolmogorov-Smirnov Test

\begin{tabular}{llr}
\hline & & Nilai Post Test \\
\hline $\mathrm{N}$ & & 25 \\
\hline Normal Parameter & & 85.100 \\
\hline \multirow{2}{*}{ Most Extreme Differences } & Mean & 84.001 \\
\cline { 2 - 3 } & Std. Deviation & 0.185 \\
\cline { 2 - 3 } & Absolute & 0.185 \\
\cline { 2 - 3 } & Positive & -0.122 \\
\cline { 2 - 3 } & Negative & 0.185 \\
\hline Test Statistic & $0.028^{\mathrm{c}}$ \\
\hline Asymp. Sig. (2-tailed) & \\
\hline a. Test distribution is Normal. & \\
b. Calculated from data. & \\
c. Lilliefors Significance Correction. & \\
\hline
\end{tabular}

Sumber: Data Sekunder, diolah (2017)

Sedangkan hasil uji terhadap nilai signifikansi posttest sebesar 0,028. Karena nilai signifikansi posttest $<0,05$ dengan demikian, data posttest pun tidak terdistribusi normal. Karena sampel tidak terdistribusi normal, maka melihat signifikansi peningkatan hasil belajar digunakan uji Wilcoxon.

\section{(2) Uji Wilcoxon}

Uji Wilcon digunakan untuk menguji apakah ada perbedaaan nilai tengah antara dua sampel (Pujiati \& Rusliah, 2001). Uji Wilcoxon dilakukan apabila terdapat satu atau dua data dari dua kelompok yang diperoleh terdistribusi tidak normal. Jika probabilitas yaitu asymptot signifikansi > 0.05 , maka $\mathrm{H}_{\mathrm{o}}$ diterima, sehingga dapat disimpulkan tidak ada perbedaan yang signifikan antara skor pretest dan posttest berupa peningkatan hasil belajar, sedangkan jika probabilitas yaitu asymptot signifikansi $<0,05$, maka $\mathrm{H}_{\mathrm{o}}$ ditolak, sehingga dapat disimpulkan ada perbedaan yang signifikan antara skor pretest dan posttest berupa peningkatan hasil belajar. 
Tabel 7. Uji Wilcoxon

\begin{tabular}{llccc}
\hline & & $\mathrm{N}$ & Mean Rank & Sum of Ranks \\
\hline Nilai Posttest - & Negative Ranks & $1^{\mathrm{a}}$ & 1.50 & 1.50 \\
\cline { 2 - 5 } Nilai Pretest & Positive Ranks & $23^{\mathrm{b}}$ & 12.98 & 298.50 \\
\cline { 2 - 4 } & Ties & $1^{\mathrm{c}}$ & & \\
\cline { 2 - 4 } & Total & 25 & & \\
\hline a. Nilai Posttest $<$ Nilai Pretest & & & \\
b. Nilai Posttest $>$ Nilai Pretest & & & \\
c. Nilai Posttest & $=$ Nilai Pretest & & & \\
\end{tabular}

Sumber: Data Sekunder, diolah (2017)

Tabel 8. Test Statistics ${ }^{\mathrm{a}}$

\begin{tabular}{cr}
\hline & Nilai Post Test - Nilai Pre Test \\
\hline $\mathrm{Z}$ & $-4.250^{\mathrm{b}}$ \\
\hline Asymp. Sig(2-tailed) & 0.000 \\
\hline a. Wilcoxon Signed Ranks Test, b. Based on negative ranks.
\end{tabular}

Sumber: Data Sekunder, diolah (2017)

Dari hasil pengolahan data statistik diperoleh bahwa asymptot signifikansi $<0.05$, maka $\mathrm{H}_{\mathrm{o}}$ ditolak yang artinya ada perbedaan yang signifikan antara nilai pretest dan posttest berupa peningkatan hasil belajar.

\section{(3) Analisa Angket}

Data kualitatif adalah data hasil isian angket yang berisi tentang respon mahasiswa tentang pembelajaran menggunakan game edukasi. Angket yang digunakan bersifat tertutup, artinya peneliti membatasi alternatif jawaban yang dipilih oleh responden sesuai dengan isi item angket. Angket dalam penelitian ini digunakan sebagai data pendukung untuk memperoleh data dan nilai informasi tentang sikap atau respon mahasiswa terhadap penggunaan game edukasi untuk meningkatkan hasil belajar mahasiswa pada pembelajaran Basic Computer Programming. Pengolahan angket ini menggunakan skala likert. Jumlah skor ideal untuk seluruh item $=5 \times 15$ × $25=1875$, dimana angkat 5 adalah skor tertinggi untuk tiap pernyataan, 15 adalah jumlah seluruh pertanyaan, 25 adalah jumlah seluruh siswa. 
Tabel 9. Jumlah Nilai

\begin{tabular}{lccc}
\hline \multicolumn{1}{c}{ Penilaian } & Jumlah Soal & $\begin{array}{c}\text { Jumlah } \\
\text { Mahasiswa }\end{array}$ & Total Nilai Maksimum \\
\hline Sangat setuju (5) & 15 & 25 & 1875 \\
\hline Setuju (4) & 15 & 25 & 1500 \\
\hline Kurang setuju (3) & 15 & 25 & 1125 \\
\hline Tidak setuju (2) & 15 & 25 & 750 \\
\hline Sangat tidak setuju (1) & 15 & 25 & 375 \\
\hline
\end{tabular}

Sumber: Data Sekunder, diolah (2017)

Berdasarkan hasil perhitungan angket dengan menggunakan skala likert, maka didapat skor sebesar 1568, jadi berdasarkan data diatas maka tingkat persetujuan responden (kelas eksperimen) terhadap penggunaan media game edukasi pada mata basic computer programing, yaitu 1568: $1875=83.62 \%$ dari yang diharapkan (100\%). Jadi berdasarkan data yang diperoleh dari 25 responden, maka angka 1568 terletak pada daerah setuju dan sangat setuju artinya media game edukasi berperan efektif dalam membantu mahasiswa mempelajari materi dasar konsep computer programming.

Berdasarkan hasil analisis terhadap pernyataan angket rata-rata mahasiswa merespon positif penggunaan games edukasi. Berdasarkan persentase lebih dari $70 \%$ atas terlihat bahwa responden menyetujui bahwa mereka lebih memahami dan tidak merasa bosan pada pembelajaran menggunakan games edukasi sesuai dengan penelitian yang dilakukan oleh Michail N.Giannakos (Giannakos, 2013) berjudul permainan edukatif yang menyenangkan dan factor-faktor yang mempengaruhi kinerja pembelajaran.

\section{KESIMPULAN}

Berdasarkan penelitian yang sudah dilakukan, diperoleh kesimpulan bahwa aplikasi mobile learning ini dapat meningkatkan kemampuan dan hasil belajar siswa pada mata kuliah computer programming, hal itu dilihat dari hasil normalisasi gain yang diperoleh sebesar 0,52 atau 52\% termasuk ke dalam kategori sedang atau sebagian besar mahasiswa mengalami peningkatan hasil belajar. Berdasarkan data yang diperoleh dari 25 responden, maka angka 1568 terletak pada daerah setuju dan sangat 
setuju artinya media game edukasi berperan efektif dalam membantu mahasiswa mempelajari dan memahami materi dasar konsep computer programming.

Aplikasi mobile learning yang diterapkan dalam pembelajaran adalah aplikasi blockly dan scratch. Dengan masing-masing mahasiswa menggunakan aplikasi dalam smartphone nya untuk memahami pembelajaran. Bagi mahasiswa yang tidak memiliki smartphone menggunakan PC, sehingga dapat disimpulkan bahwa penggunaan mobile learning cukup efektif digunakan untuk meningkatkan hasil belajar mahasiswa dilihat dari nilai normalisasi gain dan respon belajar mahasiswa.

Saran hasil penelitian dapat dilihat dari respon mahasiswa terhadap penggunaan games edukasi yaitu berdasarkan hasil analisis terhadap pernyataan angket rata-rata mahasiswa merespon positif penggunaan games edukasi, dan berdasarkan persentase lebih dari $70 \%$ atas terlihat bahwa responden menyetujui bahwa mereka lebih memahami dan tidak merasa bosan pada pembelajaran menggunakan game edukasi.

\section{DAFTAR PUSTAKA}

Arikunto, S. (2013). Dasar-dasar Evaluasi Pendidikan. Jakarta: PT Bumi Aksara.

Arsyad, A. (2015). Media Pembelajaran. Jakarta: PT. Rajagrafindo Persada.

Blockly. (2016). Permainan Blockly Diakses dari: https://blockly.games/?lang=id

Daniel, W. W. (n.d.). Kolmogorov-Smirnov Test Applied Nonparametric Statistics (2nd ed.). Boston: PWS-Kent Publishing Company.

Djamarah, S. B., \& Zain, A. (2013). Strategi Belajar Mengajar. Jakarta: PT Rineka Cipta.

Gall, M. D, Gall, J. P., Borg, W. R. (2007). Educational Research: An Introduction. New York: Pearson Education Inc.

Giannakos, M. N. (2013). Enjoy and learn with educational games: Examining factors affecting learning performance. Computers and Education, 68, 429-439. https://doi.org/10.1016/j.compedu.2013.06.005

Joshi, A., Kale, S., Chandel, S., \& Pal, D. (2015). Likert Scale: Explored and Explained. British Journal of Applied Science \& Technology, 7(4), 396-403. https://doi.org/10.9734/bjast/2015/14975

Knuth, D. E. (1997). The Art of Computer Programming. Boston: Addison-Wesley.

Koentjaraningrat. (1990). Kebudayaan, Mentalitas dan Pembangunan. Jakarta: Gramedia Pustaka Utama.

Meltzer, D. E. (2002). The relationship between mathematics preparation and 
conceptual learning gains in physics: A possible "'hidden variable"” in diagnostic pretest scores. https://doi.org/10.1119/1.1514215

Pujiati, S. A., \& Rusliah, N. (2001). Penggunaan R dalam Psikologi. Jakarta: Academic Publisher.

Rearick, B. (2017). Blockly - 21th Century Skills Innovtion Library. Ann Arbor: Cherry Lake Publishing.

Scratch. (2016). Scratch - Imagine, Program, Share. Diakses dari: https://scratch.mit.edu/projects/editor/?tutorial=getStarted

SPSS Versi 12. (2008). Statistical Package for the Social Sciences 12.0. Diakses dari: https://spss.software.informer.com/12.0/

Sugiyono. (2012). Metode Penelitian Kuantitatif Kualitatif dan R\&D. Bandung: Alfabeta.

Suharsimi Arikunto, Supardi, S. (2015). Penelitian Tindakan Kelas. Jakarta: PT Bumi Aksara.

Sung, H. Y., \& Hwang, G. J. (2013). A collaborative game-based learning approach to improving students' learning performance in science courses. Computers and Education, 63, 43-51. https://doi.org/10.1016/j.compedu.2012.11.019

Sweigart, A. (2016). Scratch Programming Playground: Learn to Program by Making Cool Games. William Pollock. 